\title{
EFFECTS OF DIETS WITH DIFFERENT PROTEIN LEVEL FOR COBIA (Rachycentron canadum) GROWTH IN CONTROLLED TANK
}

\author{
Lulus Setianingsih*1, Limin Santoso ${ }^{* 2}$, dan Suryadi Saputra*3
}

\begin{abstract}
The feed given to cobia's juvennile (Rachycentron canadum) still uses expensive factory-made feed to be the basis of this research. This aims of this research to examine the effect of feed formula with different protein levels on optimal growth cobia. This research method used a completely randomized design $(C R D)$ with three treatments and three replications. The treatment in this study were different protein level commercial feed (as control/46\%), and formula feed (protein P1 46\% and P2 protein 48\%). The parameters tested included absolute weight, daily growth rate, feed conversion ratio, protein retention, and survival rate. The data obtained were analyzed by analysis of variance and continued with the duncan test with a 95\% confidence interval. The results showed that the growth of absolute weight and daily growth rates generated from each treatment were significantly different ( $p<0.05), K\left(80.30 \pm 11.20^{c} \mathrm{~g}\right.$ and $1.78 \pm 0.25^{c} \mathrm{~g} /$ day $), P 1$ $\left(21.87 \pm 1.95^{a} \mathrm{~g}\right.$ and $0.49 \pm 0.05^{a} \mathrm{~g} /$ day $), P 2\left(37.43 \pm 3.29^{b} \mathrm{~g}\right.$ and $0.83 \pm 0.07^{b}$ g/day).
\end{abstract}

Keywords: Cobia's juvennile, Controlled Tank, Feed, Growth, Protein

\section{Pendahuluan}

Ikan cobia (Rachycentron canadum) merupakan salah satu ikan karnivora laut yang relatif baru dalam bidang akuakultur dan berpotensi tinggi untuk diproduksi secara massal (Liao dan Leano, 2007).Ikan cobia memiliki rasa yang enak dengan tekstur dagingnya yang padat, selain itu ikan ini juga memiliki kandungan gizi yang tinggi khususnya omega 3, EPA, dan DHA (Pazos et al., 2005).Cobia memiliki pertumbuhan yang relatif cepat dan termasuk golongan ikan euryhaline dan eurythermal (Resley et al., 2006), sehingga mampu beradaptasi dalam kondisi budidaya baik di keramba jaring apung (KJA) maupun di dalam bak-bak terkontrol.

Salah satu kendala yang dihadapi dalam kegiatan budidaya ikan cobia yaitu belum tersedianya pakan buatan khusus untuk ikan cobia, pakan yang diberikan merupakan pakan buatan pabrik untuk ikan kakap, bawal maupun kerapu yang harganya cukup tinggi. Pakan dibutuhkan oleh ikan untuk

\footnotetext{
${ }^{1}$ E-mail: lulus.setiani22@gmail.com

2 Jurusan Perikanan dan Kelautan, Fakultas Pertanian, Universitas Lampung

Jl. Prof. S. Brodjonegoro No.1 Gedong Meneng Bandar Lampung, 35145

${ }^{3}$ Perekayasa Balai Besar Perikanan Budidaya Air Laut (BBPBL) Lampung
} 
menjaga kelangsungan hidup dan pertumbuhannya. Kelengkapan dan keseimbangan nutrisi dengan jumlah energi yang cukup dalam pakan mutlak diperlukan untuk menjaga agar pertumbuhan ikan dapat berlangsung secara normal. Protein merupakan sumber energi utama yang dibutuhkan ikan, protein merupakan senyawa organik yang terdiri dari beberapa asam amino dan berfungsi untuk pemeliharaan jaringan tubuh, pembentukan enzim, dan beberapa hormon di dalam tubuhnya (Halver, 2002). Jumlah dan kualitas protein yang diberikan akan mempengaruhi penyimpanan protein tubuh yang selanjutnya digunakan untuk pertumbuhan. Menurut Marzuki et al. (2012), peningkatan kadar protein pakan yang diberikan akan meningkatkan laju pertumbuhan ikan.

Pakan menempati urutan pertama dalam analisis biaya produksi sebesar $60-70 \%$ (Sahwan, 2004). Menurut penelitian Saputra (2016), untuk memproduksi $1 \mathrm{~kg}$ daging cobia, dibutuhkan biaya pakan sebesar 85 - 90\% dari total biaya produksi dengan nilai FCR sebesar 2 - 2,5. Tingginya harga pakan yang digunakan dalam kegiatan budidaya, dapat diimbangi dengan pengembangan pakan formula khusus ikan cobia yang terbuat dari bahanbahan berkualitas, sehingga perlu dilakukan penelitianterkait pengaruh pemberian pakan formula dengan kadar protein berbeda untuk ikan cobia. Tujuan penelitian ini untuk mengkaji pengaruh pemberian pakan formula dengan kadar protein berbeda yang optimal terhadap pertumbuhan ikan cobia (Rachycentron canadum).

\section{Metode}

\section{Persiapan pakan}

Pembuatan pakan formula diawali dengan melakukan analisa proksimat terhadap bahan baku pakan, kemudian dilakukan penimbangan bahan baku sesuai dengan formulasi (Tabel 1). Setelah itu, bahan tepung dicampur didalam mixer dan ditambahkan $3.150 \mathrm{ml}$ air secara bertahap.Selanjutnya, bahan tepung dikukus selama 15 menit.Setelah pengukusan, dilakukan pencampuran bahan tepung dengan Vitamin C, Vitamin Pre-Mix, Anti Mold, Anti oksidan hingga merata.Kemudian campuran tersebut ditambahkan dengan minyak ikan, lechitin, dan garam yang telah dilarutkan dalam $300 \quad \mathrm{ml}$ air.Selanjutnya campuran bahan tersebut ditambahkan dengan PMC. Setelah itu, bahan dicetak dan dikeringkan selama 10 jam pada suhu $50{ }^{\circ} \mathrm{C}$.

\section{Rancangan penelitian}

Tabel 1. Formulasi dan hasil proksimat pakan

\begin{tabular}{lccc}
\hline \multicolumn{1}{c}{ Bahan Baku } & \multicolumn{3}{c}{ Pakan Perlakuan } \\
\cline { 2 - 4 } Tepung Ikan & $\mathrm{K}(46 \%)$ & $\mathrm{P} 1(46 \%)$ & $\mathrm{P} 2(48 \%)$ \\
Meat and Bone Meal (MBM) & TD & 39,63 & 48,63 \\
Poultry by product Meal (PBM) & TD & 30,8 & 28,79 \\
Soy Bean Meal (SBM) & TD & 6,29 & 3,79 \\
Corn Gluten Meal (CGM) & TD & 6,1 & 3,01 \\
\hline
\end{tabular}




\begin{tabular}{lccc}
\hline Tepung Tapioka & TD & 2,5 & 2,5 \\
Tepung Terigu & TD & 4,5 & 4,5 \\
Minyak Ikan & TD & 3,5 & 3,5 \\
Lechitin & TD & 0,4 & 0,4 \\
Vitamin C & TD & 0,03 & 0,03 \\
Vitamin Pre-Mix & TD & 1,1 & 1,1 \\
Anti Mold & TD & 0,1 & 0,1 \\
Anti OX & TD & 0,04 & 0,04 \\
Enzyme & TD & 0,1 & 0,1 \\
Garam & TD & 0,1 & 0,1 \\
Suplemen & TD & 0,51 & 0,51 \\
PMC (Polymethylolcarbamide) & TD & 0,3 & 0,3 \\
\hline Jumlah & 100 & 100 & 100 \\
\hline Kadar protein $(\%)$ & 45,84 & 46,30 & 48,67 \\
Kadar lemak (\%) & 12,76 & 10,34 & 10,29 \\
Serat kasar $(\%)$ & 2,04 & 4,31 & 1,06 \\
BETN (\%) & 17,46 & 7,93 & 7,57 \\
Kadar abu $(\%)$ & 13,78 & 24,00 & 24,92 \\
Energi (kkal/kg) & 4565,98 & 4066,60 & 4046,61 \\
\hline
\end{tabular}

Keterangan: TD (tidak diketahui)

Perhitungan energi berdasarkan Furuichi (1988) (lipid: 9,4 kkal/kg, protein: 5,6 kkal/kg, karbohidrat: 4,1 kkal/kg)

Rancangan yang digunakan
dalam penelitian ini adalah Rancangan Acak Lengkap (RAL) yaitu pakan formula dengan kadar protein yang berbeda dan satu perlakuan pakan komersil sebagai kontrol. Setiap perlakuan dilakukan pengulangan sebanyak tiga kali. Perlakuan penelitian sebagai berikut:

Perlakuan 1 (K): pakan komersil dengan kadar protein $46 \%$ (kontrol).

Perlakuan 2 (P1): pakan formula dengan kadar protein $46 \%$.

Perlakuan 3 (P2): pakan formula dengan kadar protein $48 \%$.

\section{Pemeliharaan ikan}

Wadah yang digunakan dalam penelitian ini ialah bak fiber berbentuk bulat dengan kapasitas $1,5 \mathrm{~m}^{3}$ sebanyak 9 bak. Wadah ini memiliki satu inlet dibagian atas dan outlet di bagian bawah yang dilengkapi dengan pipa. Bak yang akan digunakan didesinfeksi terlebih dahulu, setelah itu bak dibilas hingga bersih dan dilakukan pengisian air sampai $70 \%$ dari volume wadah dengan 2 titik aerasi di setiap wadah.

Ikan yang digunakan yaitu ikan cobia umur 90 hari dengan berat ratarata $56,9 \pm 1,06 \mathrm{~g}$ dan panjang ratarata $21,13 \pm 0,15 \mathrm{~cm}$ yang diperoleh dari kegiatan pendederan di Balai Besar Perikanan Budidaya Laut (BBPBL) Lampung. Ikan ditebar dengan kepadatan 50 ekor/bak. Pemeliharaan ikan dilakukan selama 45 hari. Pemberian pakan dilakukan dua kali sehari pada secara $a d$ satiation. Pakan diberikan sesuai dengan perlakuan masing-masing. Penyiponan dilakukan untuk menghilangkan sisa pakan di dasar bak kemudian dilanjutkan dengan 
pergantian air $50-70 \%$ sebanyak dua kali sehari. Selain itu dilakukan pengukuran parameter kualitas air yaitu pH, DO, suhu, amoniak, salinitas, nitrit, dan amoniak.

Sampling pertumbuhan dilakukan setiap 7hari sekali dengan mengambil seluruh sampel bobot ikan yang dipelihara di setiap bak serta sampel panjang tubuh sebanyak $20 \%$ dari jumlah populasi, untuk parameter SR dilakukan dengan menghitung jumlah populasi ikan pada awal tebar dan akhir pemeliharaan. Perhitungan jumlah konsumsi pakan dengan cara menghitung selisih antara pakan yang diberikan dengan pakan yang terbuang.

\section{Analisis data}

Bobot mutlak dihitung dengan menggunakan rumus (Effendie, 1997):

$$
\mathrm{W}=\mathrm{W}_{\mathrm{t}}-\mathrm{W}_{0}
$$

Keterangan:

$\mathrm{W}=$ pertumbuhan bobot mutlak $(\mathrm{g})$

$\mathrm{W}_{\mathrm{t}}=$ bobot rata-rata ikan pada waktu akhir (g)

$\mathrm{W}_{0}=$ bobot rata-rata ikan pada waktu awal (g).

Laju pertumbuhan harian (LPH) dihitung dengan menggunakan rumus (Purnomo, 2012):

$$
\mathrm{LPH}=\underline{\mathrm{W}_{\mathrm{t}}-\mathrm{W}_{\mathrm{n}}} \underline{\mathrm{t}}
$$

Keterangan:

$$
\begin{aligned}
\mathrm{LPH}= & \text { laju pertumbuhan harian } \\
& (\mathrm{g} / \text { hari }) \\
\mathrm{W}_{\mathrm{t}}= & \text { bobot rata-rata ikan pada } \\
& \text { waktu } \mathrm{t}(\mathrm{g}) \\
\mathrm{W}_{\mathrm{n}}= & \text { bobot rata-rata ikan pada } \\
& \text { waktu awal }(\mathrm{g}) \\
\mathrm{t}= & \text { waktu pemeliharaan (hari) }
\end{aligned}
$$

Rasio konversi pakan dihitung dengan rumus (Halver dan Hardy, 2002):

$$
\mathrm{FCR}=\frac{\mathrm{P}}{\left(\mathrm{B}_{\mathrm{t}}+\mathrm{B}_{\mathrm{d}}\right)-\mathrm{B}_{0}}
$$

Keterangan :

$$
\begin{aligned}
\mathrm{P}= & \text { Jumlah konsumsi pakan }(\mathrm{g}) \\
\mathrm{B}_{\mathrm{t}}= & \text { Biomassa ikan pada akhir } \\
& \text { pemeliharaan }(\mathrm{g}) \\
\mathrm{B}_{\mathrm{d}}= & \text { Biomassa ikan mati selama } \\
& \text { pemeliharaan }(\mathrm{g}) \\
\mathrm{B}_{0}= & \text { Biomassa ikan pada awal } \\
& \text { pemeliharaan }(\mathrm{g})
\end{aligned}
$$

Retensi protein dihitung dengan menggunakan rumus (Halver dan Hardy, 2002):

Keterangan:

$$
\mathrm{RP}=\underline{\mathrm{F}-\mathrm{I}} \times 100 \%
$$

$$
\begin{aligned}
\mathrm{RP}= & \text { Retensi protein }(\%) \\
\mathrm{F}= & \text { Jumlah protein ikan pada } \\
& \text { akhir pemeliharaan }(\mathrm{g}) \\
\mathrm{I}= & \text { Jumlah protein ikan pada awal } \\
& \text { pemeliharaan }(\mathrm{g}) \\
\mathrm{P}= & \text { Jumlah protein yang } \\
& \text { dikonsumsi ikan selama } \\
& \text { pemeliharaan }(\mathrm{g}) .
\end{aligned}
$$

Tingkat kelangsungan hidup dihitung dengan menggunakan rumus (Effendie, 1997):

$$
\mathrm{SR}=\frac{\mathrm{N}_{\mathrm{t}}}{\mathrm{N}_{0}} \times 100 \%
$$

Keterangan :

$$
\begin{aligned}
\mathrm{SR}= & \text { Kelangsungan hidup }(\%) \\
\mathrm{Nt}= & \text { Jumlah ikan pada akhir } \\
& \text { pemeliharaan } \\
\mathrm{No}= & \text { Jumlah ikan pada awal } \\
& \text { pemeliharaan. }
\end{aligned}
$$

Data penelitian dianalisis secara kuantitatif berupa tabel dan grafik menggunakan aplikasi Microsoft 
Excel 2010 dan SPSS 22 kemudian dilanjutkan dengan uji normalitas dan uji anova.Apabila hasilnya berbeda nyata maka dilakukan uji lanjut dengan menggunakan Uji Duncan.
Data kualitas air dianalisis secara deskriptif dan disajikan dalam bentuk tabel, selain itu juga dilakukan perhitungan biaya pakan berdasarkan nilai FCR dan harga pakan.

\section{Hasil dan Pembahasan}

Tabel 2. Hasil pengukuran kinerja pertumbuhan ikan cobia yang diberi pakan dengan kandungan protein berbeda selama 45 hari masa pemeliharaan

Parameter penelitian

\section{Perlakuan pemberian pakan kadar} protein berbeda $(\%)$

\begin{tabular}{lccc}
\cline { 2 - 4 } & K (46) & P1 (46) & P2 (48) \\
\hline Bobot mutlak (g) & $80,30 \pm 11,20^{\mathrm{c}}$ & $21,87 \pm 1,95^{\mathrm{a}}$ & $37,43 \pm 3,29^{\mathrm{b}}$ \\
Laju pertumbuhan harian (g/hari) & $1,78 \pm 0,25^{\mathrm{c}}$ & $0,49 \pm 0,05^{\mathrm{a}}$ & $0,83 \pm 0,07^{\mathrm{b}}$ \\
Rasio konversi pakan & $1,68 \pm 0,14^{\mathrm{a}}$ & $1,70 \pm 0,12^{\mathrm{a}}$ & $2,47 \pm 0,24^{\mathrm{b}}$ \\
Retensi protein (\%) & $24,97 \pm 2,86^{\mathrm{b}}$ & $13,51 \pm 1,89^{\mathrm{a}}$ & $21,72 \pm 1,00^{\mathrm{b}}$ \\
Tingkat kelangsungan hidup (\%) & $100 \pm 0^{\mathrm{c}}$ & $81,00 \pm 3,00^{\mathrm{a}}$ & $94,00 \pm 2,00^{\mathrm{b}}$ \\
\hline
\end{tabular}

Keterangan: huruf yang berbeda dalam baris yang sama menunjukkan perlakuan yang berbeda nyata secara signifikan $(\mathrm{p}<0,05)$

Hasil penelitian pada ikan cobia yang diberi pakan dengan kadar protein berbeda selama 45 hari masa pemeliharaan ikan cobia memiliki kinerja pertumbuhan yang bervariasi (Tabel 2), tiap perlakuan mempunyai nilai bobot mutlak, laju pertumbuhan harian dan tingkat kelangsungan hidup yang berbeda secara signifikan $(\mathrm{p}<0,05)$ dengan urutan dari yang tertinggi sampai terendah yaitu $\mathrm{K}$ $\left(80,30 \pm 11,20^{\mathrm{c}} \mathrm{g}, \quad 1,78 \pm 0,25^{\mathrm{c}} \mathrm{g} / \mathrm{hari}\right.$ dan $\left.100 \pm 0^{\mathrm{c}}\right), \quad \mathrm{P} 2 \quad\left(37,43 \pm 3,29^{\mathrm{b}} \mathrm{g}\right.$, $0,83 \pm 0,07^{\mathrm{b}} \mathrm{g} /$ hari dan $\left.94,00 \pm 2,00^{\mathrm{b}}\right)$, dan P1 $\left(21,87 \pm 1,95^{\mathrm{a}} \mathrm{g}, 0,49 \pm 0,05^{\mathrm{a}}\right.$ $\mathrm{g} /$ hari dan $\left.81,00 \pm 3,00^{\mathrm{a}}\right)$. Nilai FCR pada perlakuan $\mathrm{K}\left(1,68 \pm 0,14^{\mathrm{a}}\right)$ dan perlakuan $\mathrm{P} 1\left(1,70 \pm 0,12^{\mathrm{a}}\right)$ berbeda secara signifikan $(\mathrm{p}<0,05)$ dengan perlakuan P2 $\left(2,47 \pm 0,24^{\text {b }}\right)$. Kemudian retensi protein pada perlakuan $\mathrm{K}$ $\left(24,97 \pm 2,86^{\mathrm{b}}\right)$ dan perlakuan P2 $\left(21,72 \pm 1,00^{\mathrm{b}}\right)$ berbeda secara signifikan $(\mathrm{p}<0,05)$ dengan perlakuan P1 $\left(13,51 \pm 1,89^{\mathrm{a}}\right)$.

Pakan formula P1 (46\%) dan P2 (48\%) yang digunakan dalam penelitian ini berupa pelet tenggelam berukuran $5 \mathrm{~mm}$ dengan tekstur lebih kasar dibandingkan dengan pakan kontrol yang memiliki tekstur halus. Selain itu, pakan kontrol juga memiliki aroma khas ikan yang lebih kuat dibandingkan dengan pakan formula. Hal tersebut diduga penggunaan atraktan dalam pakan formula belum optimal untuk membuat aroma dan rasa pakan yang disukai ikan cobia. Selama masa pemeliharaan ikan cobia yang diberi pakan perlakuan $\mathrm{P} 1$ dan $\mathrm{P} 2$ merespon pakan lebih lambat dan cenderung lebih cepat berhenti makan dibandingkan dengan ikan yang diberi pakan kontrol, sehingga ikan yang diberi pakan formula memiliki jumlah konsumsi pakan yang lebih 
rendah dibandingkan dengan kontrol. Menurut Houlihan et al., (2002) kebiasaan makan pada ikan dipengaruhi oleh rangsangan yang diterima sel kemosensori berupa olfaktori (indra penciuman) dan gustatori (indra perasa) yang peka terhadap bau dan rasa yang terdapat pada pakan. Olfaktori berfungsi memberikan isyarat untuk mendekati makanan, sedangkan gustatori berperan penting dalam keputusan menerima atau menolak makanan.

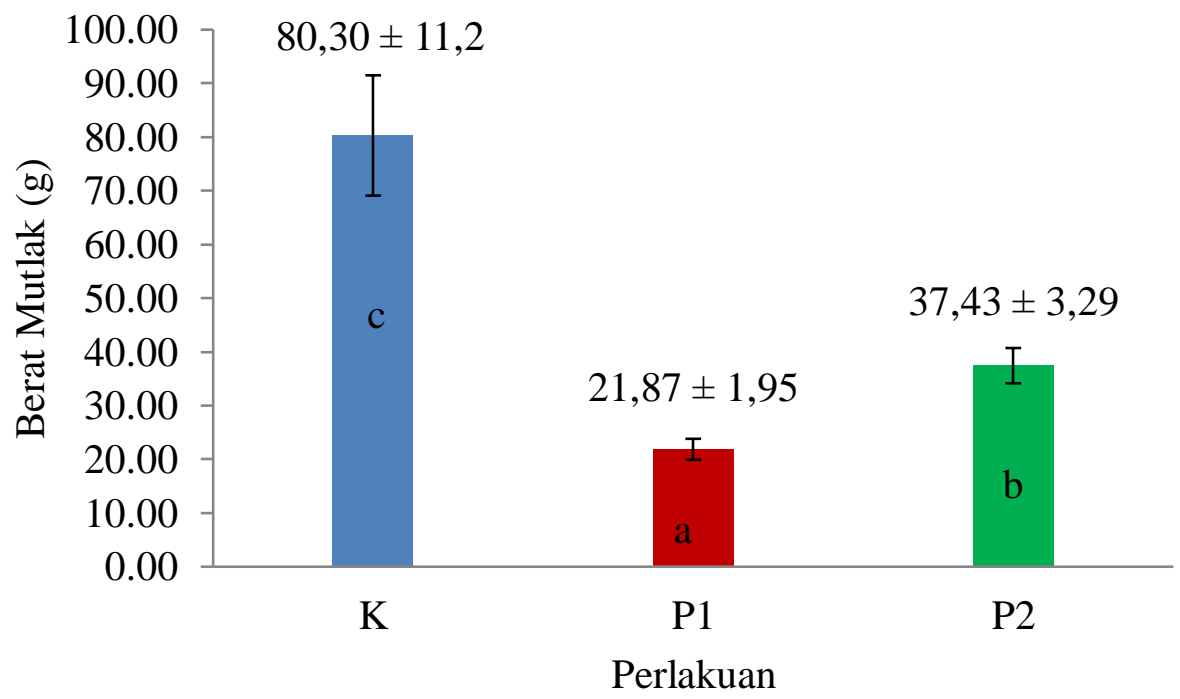

Keterangan: huruf kecil yang sama pada histogram menunjukkan perlakuan tidak berbeda nyata Gambar 1. Grafik bobot mutlak ikan cobia.

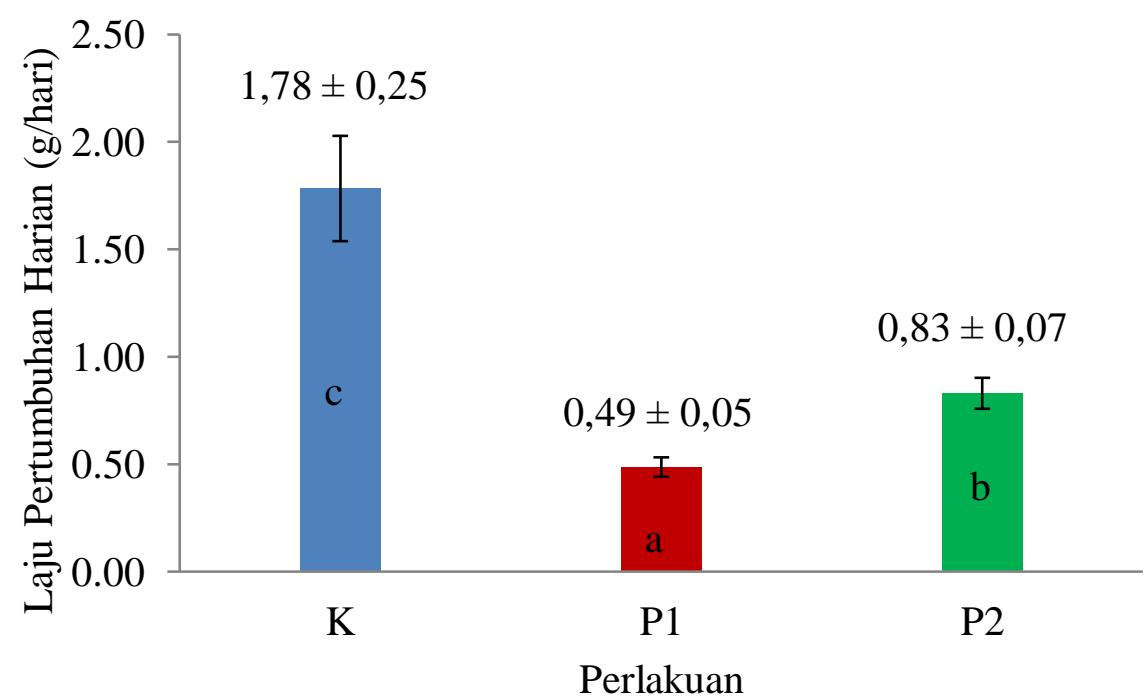

Keterangan: huruf kecil yang sama pada histogram menunjukkan perlakuan tidak berbeda nyata Gambar 2. Grafik laju pertumbuhan harian ikan cobia. 
Nilai bobot mutlak (Gambar 1), dan laju pertumbuhan harian (Gambar 2) pada P2 lebih tinggi dibandingkan dengan pakan uji P1, hasil ini sesuai dengan pernyataan Marzuki et al., (2012) bahwa peningkatan kadar protein pakan yang diberikan akan meningkatkan laju pertumbuhan ikan. Nilai bobot mutlak dan laju pertumbuhan harian pada perlakuan P2 lebih rendah dibandingkan dengan perlakuan $\mathrm{K}$, hal ini diduga karena energi yang dihasilkan pada pakan formula lebih rendah dibandingkan pakan kontrol. Keseimbangan energi dan protein dalam pakan sangat berperan dalam menunjang pertumbuhan. Ikan memperoleh sumber energinya dari pakan, dimana pada pakan ini mengandung nutrien yang berasal dari protein, lemak, dan karbohidrat. Dari total energi pakan yang diterima, hampir $60 \%$ digunakan untuk memenuhi kebutuhan pokok, seperti metabolisme dan pemeliharaan tubuh (maintenance) sedangkan sisanya (40\%) untuk pertumbuhan (Yamada, 1983). Cho et al. (1985) menyatakan bahwa $10-40 \%$ dari total energi yang dikonsumsi hilang melalui feses. Energi untuk seluruh aktivitas tersebut diharapkan sebagian besar berasal dari nutrien non protein. Apabila sumbangan energi dari bahan non protein rendah, maka protein akandidegradasi untuk menghasilkan energi sehingga fungsi protein sebagai nutrien pembangun jaringan tubuh akan berkurang (Kurnia, 2002).

Tabel 3. Hasil pengukuran kualitas air pemeliharaan ikan cobia yang diberi pakan dengan kadar protein berbeda.

\begin{tabular}{lcccc}
\hline \multicolumn{1}{c}{ Parameter } & K & P1 & P2 & $\begin{array}{c}\text { Baku } \\
\text { mutu }\end{array}$ \\
\hline $\mathrm{pH}^{* * * *}$ & $7,77-7,84$ & 7,92 & $7,79-7,86$ & $7-8,5^{*}$ \\
DO $(\mathrm{mg} / \mathrm{l})$ & $5,00-5,18$ & $5,11-5,30$ & 5,10 & $>4$ \\
Suhu $\left({ }^{\circ} \mathrm{C}\right)$ & $28,2-29,2$ & $28,8-29,2$ & $28,8-29,2$ & Alami \\
Salinitas $(\mathrm{Ppt})$ & 32 & 32 & 32 & $30-34^{*}$ \\
Nitrit $^{* * * *}(\mathrm{mg} / \mathrm{l})$ & $0,082-0,088$ & $0,084-0,090$ & $0,082-0,086$ & $0,05^{* *}$ \\
Amoniak $^{* * *}(\mathrm{mg} / \mathrm{l})$ & $0,272-0,434$ & $0,285-0,485$ & $0,294-0,597$ & $0,3^{*}$ \\
\hline
\end{tabular}

Nilai bobot mutlak dan laju pertumbuhan harian ikan cobia pada tiap perlakuan juga dipengaruhi oleh kadar serat dan abu dalam pakan yang diberikan (tabel 3). Serat kasar merupakan bagian dari karbohidrat yang telah dipisahkan dengan bahan ekstrak tanpa nitrogen (BETN) yang terutama terdiri dari pati, dengan cara analisis kimia sederhana (Tillman et al., 1998). Salma dan Gunarto (1999) menyatakan bahwa serat kasar terdiri atas selulosa, hemiselulosa, dan lignin dan dibutuhkan ikan dalam membantu proses pencernaan makanan. Apabila jumlah serat kasar berlebih dalam pakan akan menyebabkan proporsi makanan yang dapat dicerna menjadi berkurang, seperti menurunkan penyerapan lemak (Safitri, 2014). Mujiman (2008) menambahkan bahwa pakan yang mempunyai kandungan serat kasar yang tinggi dapat mengurangi 
berat badan karena serat kasar mempunyai komposisi karbohidrat kompleks yang dapat memberikan rasa kenyang dan menghentikan nafsu makan. Anggi (2010) melaporkan bahwa penggunaan serat kasar untuk pakan ikan tergantung dari spesies dan stadia pertumbuhan. Ikan karnivora kurang dapat mencerna serat, oleh karena itu direkomendasikan kandungan serat untuk pakan ikan karnivora tidak lebih dari $4 \%$, hal ini sesuai dengan hasil penelitian pada perlakuan P1 yang memiliki jumlah konsumsi pakan rendah sehingga menyebabkan pertumbuhan yang dihasilkan juga rendah.

Kadar abu merupakan mineral yang terkandung dalam suatu bahan. Komponen abu pada analisis proksimat tidak memberi nilai makanan yang penting karena abu tidak mengalami pembakaran sehingga tidak menghasilkan energi. Jumlah abu dalam bahan pakan hanya penting untuk menentukan perhitungan bahan ekstrak tanpa nitrogen meskipun abu terdiri dari komponen mineral, namun bervariasinya kombinasi unsur mineral dalam bahan pakan menyebabkan abu tidak dapat dipakai sebagai indeks untuk menentukan jumlah unsur mineral tertentu. Peningkatan kadar abu berkorelasi negatif dengan jumlah energi dalam pakan (Suparjo, 2010), hal ini sesuai dengan hasil penelitian bahwa pakan perlakuan P2 memiliki kadar abu tertinggi juga memiliki jumlah energi yang paling rendah.

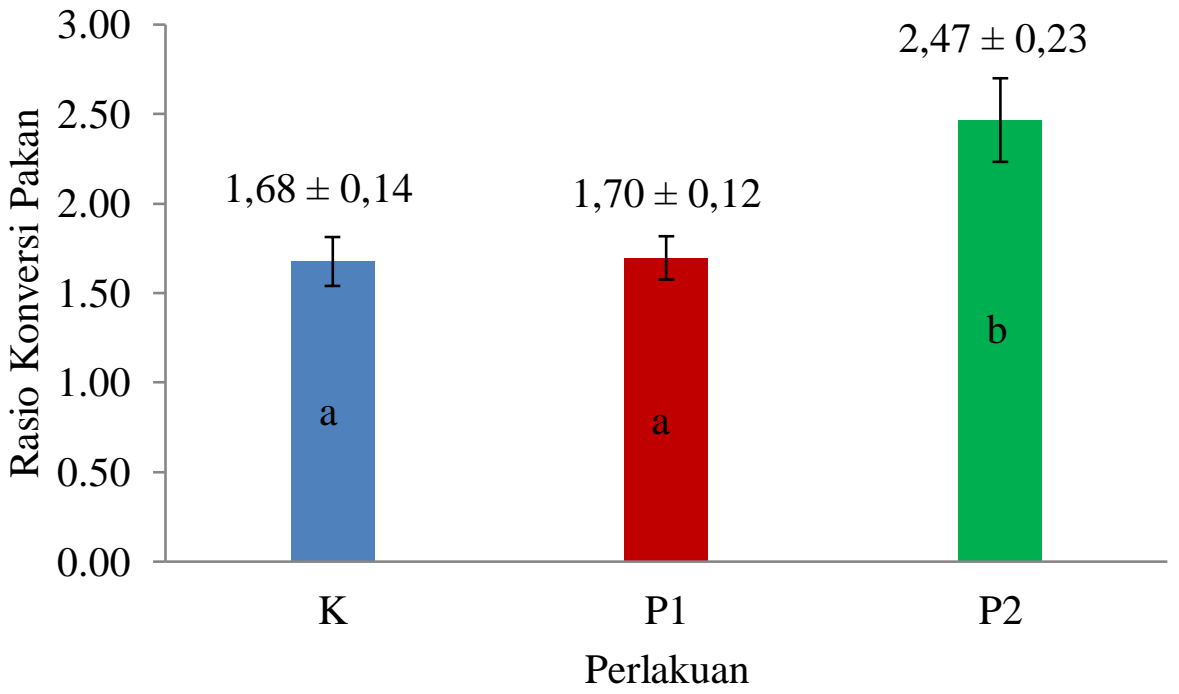

Keterangan: huruf kecil yang sama pada histogram menunjukkan perlakuan tidak berbeda nyata Gambar 3. Grafik rasio konversi pakan ikan cobia

Nilai FCR (Gambar 3) yang rendah dengan hasil pertumbuhan yang rendah pada perlakuan P1 tidak sesuai dengan pernyataan Ardita et al. (2015) bahwa semakin rendah nilai FCR akan menghasilkan nilai pertumbuhan yang tinggi, hal ini berkaitan dengan efisiensi pakan yang digunakan ikan untuk pertumbuhan. Kondisi ini dikarenakan rendahnya jumlah pakan yang dikonsumsi dan diduga sistem pencernaan ikan cobia 
tidak dalam kondisi maksimal. Sari et al. (2009) menyatakan bahwa jumlah konsumsi pakan pada ikan dipengaruhi oleh kapasitas dan pengosongan lambung atau sesuai dengan waktu ikan membutuhkan pakan (kondisi lapar).

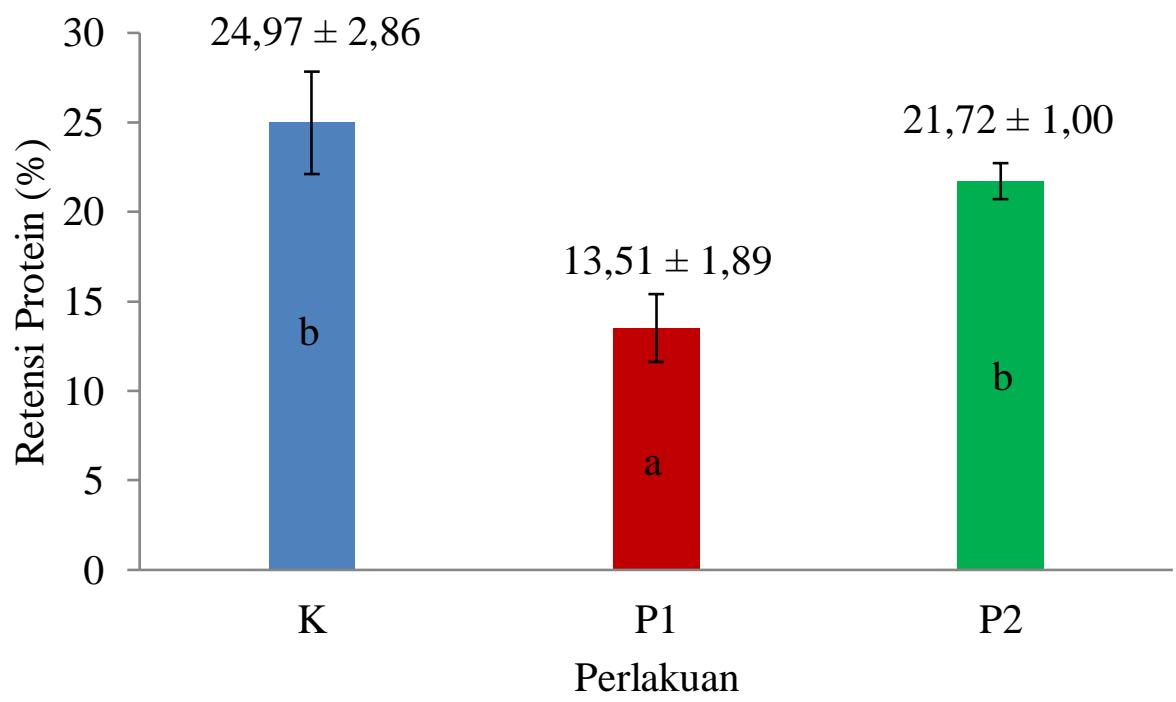

Keterangan: huruf kecil yang sama pada histogram menunjukkan perlakuan tidak berbeda nyata Gambar 4. Grafik retensi protein ikan cobia

Nilai retensi protein (Gambar 4) pada tiap perlakuan berturut-turut dari yang tertinggi sampai yang terendah adalah perlakuan $\mathrm{K}(24,97 \pm 2,86)$, Perlakuan P2 $(21,72 \pm 1,00)$, dan perlakuan P1 $(13,81 \pm 1,89)$. Hal ini menunjukkan bahwa ikan yang diberi pakan perlakuan $\mathrm{K}$ dan $\mathrm{P} 2$ mampu mengkonversi protein dalam pakan menjadi protein yang tersimpan dalam tubuhnya, sehingga memiliki pertumbuhan yang lebih tinggi dibandingkan dengan ikan yang diberi pakan perlakuan P1. Hasil tersebut sesuai dengan pendapat Maynard et al. (1979) bahwa konversi protein dalam pakan menjadi protein yang disimpan dalam tubuh bergantung dari kemampuan enzim yang terdapat dalam tubuh ikan untuk menghidrolisis substansi-substansi yang terdapat dalam pakan, sehingga tubuh mampu menyimpan protein dan selanjutnya digunakan untuk pertumbuhan.

Pengukuran kualitas air pada media budidaya ikan cobia selama 45 hari masa pemeliharaan melalui pemberian pakan dengan kadar protein berbeda yang dipelihara di bak terkontrol disajikan pada tabel 4 . Kualitas air sangat berperan penting dalam kegiatan budidaya karena akan berpengaruh terhadap proses pertumbuhan dan kesehatan ikan. Kualitas air sangat berperan penting dalam kegiatan budidaya karena akan berpengaruh terhadap proses pertumbuhan dan kesehatan ikan. Kualitas yang baik (sesuai standar budidaya) akan mendukung pertumbuhan yang optimal. Hasil pengukuran kualitas air pada media budidaya ikan cobia menujukkan bahwa nilai nitrit dan amoniak pada tiap perlakuan memiliki kisaran nilai 
yang melebihi ambang batas hal ini diduga akibat sisa metabolisme dan sisa pakan yang banyak terbuang di dalam kolam. Menurut Brune et al. (2003) dari seluruh nitrogen dalam pakan yang diberikan kepada ikan, sebanyak $25 \%$ digunakan untuk tumbuh, $60 \%$ dikeluarkan dalam bentuk NH3 dan $15 \%$ dikeluarkan bersama feses.

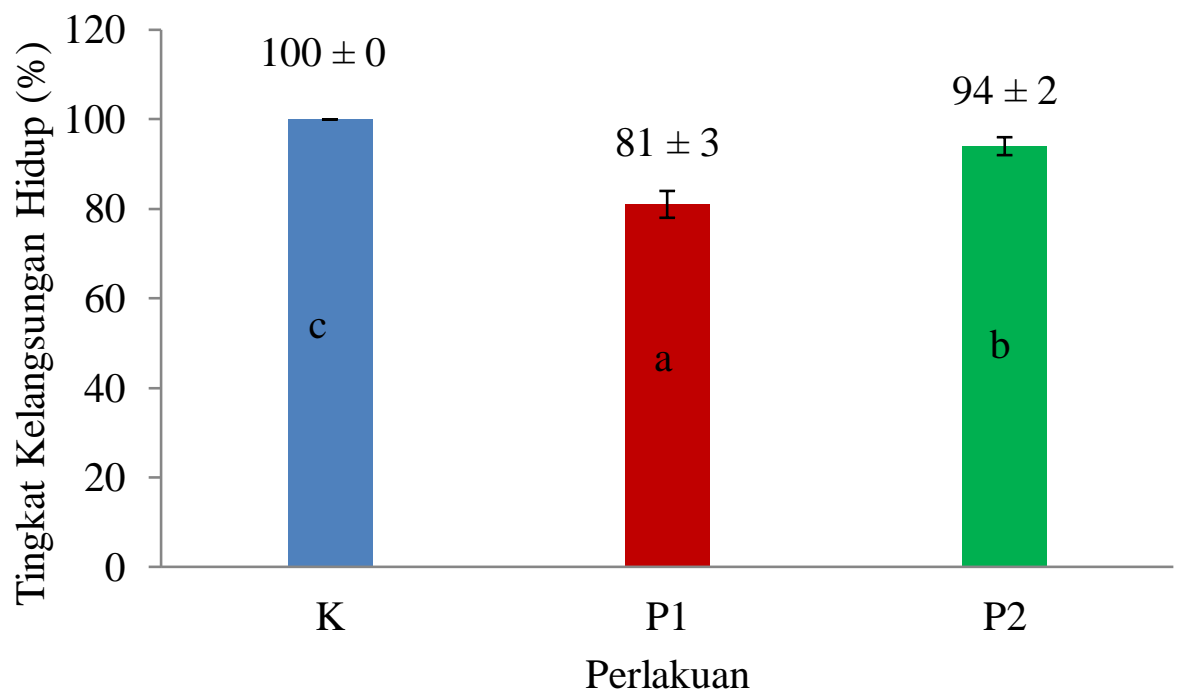

Keterangan: huruf kecil yang sama pada histogram menunjukkan perlakuan tidak berbeda nyata Gambar 5. Grafik tingkat kelangsungan hidup ikan cobia

Tabel 4. Hasil uji laboratorium penyakit pada ikan cobia

\begin{tabular}{lcc}
\hline \multicolumn{1}{c}{ Parameter } & Hasil uji & Spesifikasi metode \\
\hline Parasit & Negatif (-) & Mikroskopis \\
Bakteri & Positif (+) dari hati, & TSA : Media umum \\
& limpa, dan luka pada & \\
& media TSA & \\
& Negatif (-) pada media & TCBS : Media selektif \\
& TCBS & \\
Jamur & Negatif $(-)$ & PDA : media selektif \\
& & jamur \\
Irodovirus & Negatif $(-)$ & PCR \\
\hline
\end{tabular}

Tingkat kelangsungan hidup (Gambar 5) yang didapat setelah 45 hari pemeliharaan ikan cobia pada tiap perlakuan berbeda nyata secara signifikan $\quad(\mathrm{p}<0,05), \quad$ dengan perlakuan $\mathrm{K}$ mempunyai nilai kelangsungan hidup sebesar $100 \pm 0$,

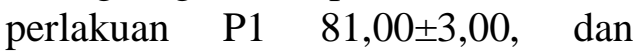


perlakuan P2 94,00 $\pm 2,00$. Nilai kelangsungan hidup yang diperoleh dari ketiga perlakuan ini masih optimal untuk kegiatan budidaya ikan.Kematian ikan pada perlakuan P1 dan P2 terjadi pada saat awal dan menjelang akhir pemeliharaan.Ikan yang mati pada awal pemeliharaan diduga karena stres akibat aerasi yang mati saat dilakukan sampling pada minggu ke-1, hal tersebut juga mengakibatkan kondisi ikan menjadi lemah sehingga diduga menjadi pemicu kematian ikan di saat menjelang akhir penelitian.Hasil pengamatan secara visual menunjukkan bahwa ikan yang dalam kondisi lemah tersebut kurang merespon pakan yang diberikan, memiliki ciri dan tingkah laku yang tidak umum yaitu dengan memiliki warna tubuh yang gelap dan berenang mengelilingi wadah pemeliharaan. Kondisi ini menjadi lebih parah saat terjadi penurunan kualitas air yang ditandai dengan peningkatan kadar nitrit dan amoniak dalam wadah pemeliharaan pada minggu ke-4. Hasil uji laboratorium (Tabel 4) menunjukkan bahwa ikan uji dari perlakuan P1 dan P2 terinfeksi bakteri, menurut Anderson (1974) penyakit pada ikan akan muncul jika terjadi interaksi antara kondisi lingkungan yang tidak layak, keberadaan patogen, dan kondisi ikan yang lemah. Austin (1999) menambahkan bahwa menurunnya kualitas lingkungan akan menyebabkan patogen berkembang dengan pesat. Kualitas air yang buruk karena meningkatnya senyawasenyawa beracun (toxicant) seperti amoniak dan nitrit dapat mempengaruhi tingkat kesehatan ikan. Dalam kosentrasi rendah senyawa tersebut menyebabkan stress pada ikan yang dapat menurunkan daya tahan tubuh sehingga peluang terjadinya infeksi pada ikan semakin besar. Upaya yang dilakukan untuk mengurangi kematian ikan akibat infeksi bakteri yaitu dengan penambahan vitamin $\mathrm{C}$ kedalam pakan melalui teknik semprot dan perendaman ikan uji dengan larutan acriflavine sebanyak 3 - 4 ppm dalam waktu 1 jam selama 7 hari berturutturut.

Tabel 5. Hasil perhitungan biaya pakan ikan cobia

\begin{tabular}{lccc}
\multirow{2}{*}{$\begin{array}{c}\text { Parameter pengukuran } \\
\text { biaya pakan }\end{array}$} & \multicolumn{3}{c}{$\begin{array}{c}\text { Perlakuan pemberian pakan kadar protein } \\
\text { berbeda (\%) }\end{array}$} \\
\cline { 2 - 4 } & K (46) & P1 (46) & P2 (48) \\
\hline Harga pakan uji (Rp) & 20.000 & 13.475 & 13.896 \\
FCR & 1,68 & 1,70 & 2,47 \\
Biaya pakan (Rp) & 33.600 & 22.907 & 34.323 \\
\hline
\end{tabular}

Kegiatan budidaya ikan cobia di Indonesia memiliki potensi ekonomi yang besar untuk terus dikembangkan, berbagai instansi pemerintahan maupun akademisi berusaha melakukan berbagai inovasi dalam pemenuhan kebutuhan budidaya ikan ini termasuk pakan. Pemerintah melalui Kementerian Kelautan dan Perikanan 
mencanangkan program gerakan pakan mandiri sebagai upaya untuk meningkatkan hasil produksi budidaya perikanan dengan cara menekan biaya produksi pakan. Pakan uji yang digunakan dalam penelitian ini merupakan pakan formula yang memiliki harga lebih rendah dengan pakan komersil (Tabel 5). Pakan uji pada perlakuan P1 dan P2 memiliki harga Rp.13.475,00/kg dan Rp.13.896,00/kg sedangkan harga pakan komersil sebesar Rp. $20.000,00 / \mathrm{kg}$, dalam 45 hari masa pemeliharaan ikan cobia dalam bak terkontrol pada perlakuan K, P1, dan P2 didapatkan biaya pakan sebesar Rp.33.600,00/kg, Rp.22.907,00 / kg, dan Rp.34.323,00/kg. Penggunaan pakan formula P2 (48\%) memiliki biaya pakan yang tinggi akibat FCR yang lebih tinggi dibandingkan dengan pakan formula P1 (46\%), hal ini diimbangi dengan kinerja pertumbuhan pakan P2 (48\%) yang juga lebih tinggi dibandingkan dengan P1 (46\%). Namun biaya pakan yang dibutuhkan pada pakan formula P2 (48\%) dan kinerja pertumbuhan yang dihasilkan masih lebih rendah dibandingkan dengan pakan komersil, sehingga menyebabkan penggunaan pakan formula belum efektif dalam kegiatan budidaya cobia.

\section{Kesimpulan dan Saran}

Pemberian pakan formula
dengan kadar protein berbeda
berpengaruh terhadap pertumbuhan
ikan cobia yang dipelihara di bak
terkontrol, pakan formula P2 (48\%)
memiliki hasil bobot mutlak dan laju
pertumbuhan harian yang lebih tinggi
dibandingkan pakan P1 (46\%).

Perlu dilakukan penelitian lanjutan dengan mengevaluasi pakan formula dengan menambah atraktan, mengurangi kadar serat dan abu agar pertumbuhan yang dihasilkan dapat melampaui atau sama dengan pertumbuhan yang dihasilkan oleh pakan komersil, sehingga dapat diterapkan oleh para pembudidaya.

\section{Daftar Pustaka}

Anderson, D.P. 1974. Fish Immunology. Publication Inc. Ltd. 218 hal.

Anggi, L. 2010. Pemberian Senyawa Osmolit Organik Taurin Pada Pakan Ikan Rucah Dan Pellet Terhadap Laju Pertumbuhan Cobia (Rachycentron canadum) Di Balai Besar Pengembangan Budidaya Laut (BBPBL) Lampung. Skripsi. Universitas Lampung, Lampung.

Ardita, N., Agung, B., \& Siti, L.A.S. 2015.Pertumbuhan dan Rasio Konversi Pakan Ikan Nila (Oreochromis niloticus) dengan Penambahan Prebiotik. Bioteknologi 12(1): 16 - 21 .

Austin, B. 1999. The effects of pollution on fish health. Journal of Applied Microbiology Symposium Suplement: 2348 - 2428.

Brune, D.E., Schwartz, G., Eversole, A.G., Collier, J.A., \& Schwedler, T.E. 2003. Intensification of pond aquaculture and high rate photosynthetic systems. Aquaculture Engineering 28: 65 86.

Cho, C.Y., Cowey, C.B., \& Watanabe, T. 1985. Finfish Nutrition in Asia. Methodological Approaches to Research and 
Development. IDRC, Ottawa. 154 hal.

Halver, J.E., \& Hardy, R.W. 2002. Fish Nutriton Third Edition. Elsevier Science, United State of America.

Houlihan, D., Boujard, T., \& Jobling, M. 2002. Food Intake in Fish. Oxford, Blackwell Science, UK. $25-48$.

Kurnia, A. 2002. Pengaruh Pakan dengan Kandungan Protein dan Rasio Energi Protein yang Berbeda terhadap Efisiensi Pakan dan Pertumbuhan Benih Ikan Baung (Mystus nemurus CV.). Thesis. Program Pascasarjana, Institut Pertanian Bogor, Bogor. 54 hal.

Liao, I.C. \& Leano, E.M. 2005.Cobia Aquaculture in Taiwan.World Aquaculture. 36 (1): 4.

Marzuki, M., Astuti, N.W.W, \& Suwirya, K. 2012. Pengaruh Kadar Protein dan Rasio Pemberian Pakan Terhadap Pertumbuhan Ikan Kerapu Macan (Epinephelus fuscoguttatus). Jurnal Ilmu dan Teknologi Kelautan Tropis. 4 (1): $55-65$.

Maynard, L.A., Loosli, J.K, Hintz, H.F., \& Warner, R.G. 1979. Animal Nutrition Seven Edition. Mcgraw-Hill Book Company, New Delhi

Mudjiman, A. 2008. Makanan Ikan. Penebar Swadaya, Jakarta.

Pazos, M., Gallardo, J.M., Torres, J.L. \& Medina, I. 2005.Activity of Grape Polyphones as Inhibitors Of The Oxidation Of Fish Lipids and Frozen Fish Muscle. Food Chemistry. 92 (3): 547 - 557.

Purnomo, P.D. 2012. Pengaruh Penambahan Karbohidrat pada Media Pemeliharaan terhadap Produksi Intensif Nila
(Oreochromis niloticus). Skripsi. Universitas Diponegoro, Semarang.

Safitri, F.E. 2014. Pemanfaatan Limbah Padat Surimi Ikan Swanggi (Priacanthus macracanthus) Secara Kimiawi terhadap Kandungan Nutrisi Sebagai Alternatif Bahan Pakan Ikan. Skripsi. Universitas Airlangga, Surabaya.

Sahwan, F. 2004. Pakan Ikan Ekonomi dan Udang: Formulasi, Pembuatan, Analisa Ekonomi. Penebar Swadaya, Jakarta. 96 hal.

Salma \& Gunarto, L. 1999. Tinjauan Ilmiah Riset Biologi dan Bioteknologi Pertanian: Enzim Selulase dari Trichoderma spp. Jurnal Balai Penelitian Bioteknologi Tanaman Pangan.

Saputra, S. 2016. Evaluasi Sumber Protein Alternatif Berbasis Perairan Sebagai Bahan Baku Pakan Juvenil Ikan Cobia (Rachycentron canadum). Disertasi. Institut Pertanian Bogor, Bogor. 121 hal.

Tillman, A.D., Hartadi, S., Reksodiprojo, S., Prawirokusumo, \& Lebdosoekojo. 1998. Ilmu Makanan Ternak Dasar. Cetakan keenam. Gajah Mada University Press, Yogyakarta. $422 \mathrm{Hal}$.

Yamada, R. 1983. Pond production system: Feed and Feeding Practice in Warmwater Fish Pond. Principles and Practices of Pond Aquaculture: A state of the art reviews. Oregon. pp. 117-144. 
